\title{
Report on the Conference of the International Commission of Ju- rists on "Development and the Rule of Law" held at The Hague, 27 April - 1 May, 1981
}

\author{
By David Kennedy
}

\section{Introduction}

The quadrennial meeting of the International Commission of Jurists (ICJ) held at The Hague from April 27 - May 1, 1981, coincided with a Commission conference devoted to "Development and the Rule of Law". The conference was meant to culminate a series of regional seminars and meetings sponsored by the ICJ over the past several years which had considered topics in the human rights field of particular interest to third world nations. As such, the 1981 meeting not only formalized a pre-existing commitment to development related issues by the Commission, but signaled a fundamental shift in the way the organization envisions the role of lawyers and the "Rule of Law". More than a simple change in organizational focus or tactic, the increased concern for development as a human rights problem amounts to a fundamental realignment of ICJ thinking about the meaning of human rights and law*.

The ICJ conference sought to reorganize the constellation of human rights law to de-emphasize civil and political rights, recognize the importance of economic, social and cultural rights, and elevate a rather loosely defined notion of "development" to some, also rather hazy legal status. The de-emphasis of civil and political rights seemed fueled by at least an unconscious appreciation of their increasing irrelevance outside the developed world. Generally a luxury, often elitist and arguably a palliative diverting attention from the need for thorough social reform, this bundle of legal notions, while conceived internationally by the last generation as a response to the brutal inhumanity of facism, has seemed increasingly beside the point in the face of what must be considered the greatest contemporary threat to human dignity: the perpetually grinding poverty of underdevelopment.

Economic, social and cultural rights would at first glance seem to fully cover the territory left unprotected by civil and political rights. What, after all, might development be, except the achievement of these rights? For a number of reasons, however, appealing variously to both progressive and traditional members of the ICJ, the contemplated shift seemed different from a simple replacement of political with economic rights. Those who sought the status of "legal right" for development were hesitant to attach it strictly to the

* The roots of this shift are very ably as well as very readably described in Philip Alston's excellent work 'Development and the Rule of Law: Prevention Versus Cure as a Human Rights Strategy، which was prepared as a background paper for the conference and is available from the ICJ Secretariat in Geneva. 
aspirational International Covenant of Economic, Social and Cultural Rights. They meant more by development and sought a more internationalized responsibility than was there provided for. Better, it seemed, to hook the new concerns on a fresh justification, free of the ideological baggage and limitations associated with the confrontation of political and economic rights. Oddly enough, this strategy seemed to permit the argument that these new notions, going beyond mere economic and social rights, could be seen as something hardly novel, but rather as the working out of provisions of the UN Charter. As to the "development rights" themselves, the ICJ remained Delphic. Were they the full achievement of civil, political, economic, social and cultural rights by nations for individuals, or was something more implied, perhaps the achievement of a communal and international solidarity which would render the accepted nature of pre-existing rights meaningless? If the second, the shift represents of profound redefinition of the Rule of Law. If the first, the whole discussion could be dismissed as so much terminological hot air. Interesting in the conference and in the recent work of the ICJ Secretariat is the sense that they mean more the second than the first, a change which could have a complex impact on our view of international law, of development and of the role of lawyers.

\section{Development of the Rule of Law}

Investigating the relationship theoretically and practically, between what might broadly be called the "civil" and "economic" halves of the old notion of an international "Rule of Law" has been a substantial part of the stock in trade of human rights scholars at least since the two sets of rights were given international legal status in the two International Covenants on, respectively, Civil and Political, and Economic, Social and Cultural Rights in 1955. Theoretically we have wondered if somehow one set precluded the other, perhaps by requiring an enforcement apparatus or institutional structure incompatible with the achievement of the other. Practically, we wondered if it was justifiable or perhaps obligatory to postpone the achievement of one until the other had been achieved. Could, or might, for example, third world nations postpone what was euphemistically referred to as "full implementation" of civil rights in order to bring about the development thought necessary to achieve economic rights? We wondered also whether the achievement of one set of rights might make achievement of the other easier or even inevitable. Might, for example, fully implemented civil rights create the institutional pressures necessary for meaningful political freedom? Most true believers in human rights preferred the comforting view that these sets of rights were complementary, mutually reinforcing, and inseparable.

For the purposes of understanding in an abstract way the change in ICJ thinking represented by the conference, it may be useful to think in terms of rather stereotypical conceptions of the role of law in achieving human dignity. To the extent the ICJ embodied a unified vision of an "international Rule of Law" previously, their view reflected this optimism. This, what might be termed "old" view, preferred to see these sets of rights as complementary, even if the ICJ's work was deeply influenced by an East-West ideologi- 
cal conflict which emphasized their incompatibility. The interesting thing is that this view seemed more than a preference by commited advocates. It seemed fundamental to the struggle to implement an international rule of law that the "rule" implemented be unified, or wholistic or internally consistant. It is not difficult to imagine why this was so. The goal of such a Rule was human freedom or dignity, indivisible conceptions whose achievement could be guaranteed only by a conceptual and institutional structure which did not so to speak, destroy the village in order to save it. The whole reason the Rule of Law seemed attractive was that other organizing schemes, like anarchy and totalitarianism, seemed only able to protect dignity by denying it. If the Rule of Law package contained two sets of rights poised to devour each other, it could be subject to the same critique. Consequently, as conflicts arose within the vision of a Rule of Law, enormous psychological pressure to resolve or deny them arose as well.

One such conflict was that between political and economic rights. The first step towards harmonizing them visualized them as two sets of rights rather than two opposed conceptions of rights, dignity, or freedom. So distinguished, they could then be rendered compatible in the cheery fashion suggested. But conflict arose in at least two other ways within the "old" view of the Rule of Law. Briefly stated, one wondered first whether an winternational" Rule of Law was to be achieved nationally or internationally, and second whether it was to be achieved by and for groups or individuals. These possibilities could be seen to conflict. For example, national achievement of the Rule of Law would deny the limitation of international norms just as an international regime would deny national interpretation of the rights to be achieved. Likewise, if an individual has rights only in and of a group, he or she has no personal rights, whereas if the individual is the repository of "Rule" created rights, groups are closed out. Given the conception of rights, at any given instance they needed to exist on one level (say national and individual) and be able to claim against the other (international and group). The old view forced these conceptions into conflict with its understanding that a right someplace engendered a duty someplace else. But the old view also developed a vision of each of these oppositions which emphasized their complementarity. The Rule of Law was to be an international structure for national achievement, ensuring both the dignity of the individual and the integrity of association. Admittedly, this compromise resolution was often substituted by a denial of one or the other component - in the ICJ generally the collective and/or national aspect - but to the extent the ICJ did present a coherent program, it was this vision of complementarity.

More interesting than this emphasis on complementarity is the way the old view manipulated the relationship between these conflicts to make them go away. It seemed intuitive that there was some relationship between economic rights and a communal approach to rights as between political rights and an individual approach. Slipperyer, but also intuitive, seemed the connection between individualism and a national approach. In a first roughshod way, we might say political rights are to economic rights as individual rights are to collective rights as nationally based rights are to internationally based rights. This might be illustrated by the following pairings: 


$\begin{array}{lll}\text { political } & ---- & \text { economic } \\ \text { individual } & ----- & \text { collective } \\ \text { national } & ----- & \text { international }\end{array}$

The first brush attempt at relating these tensions to one another accords with our initial sense of what went on at the ICJ conference. One might say that the old view is on the left (political, individual, and national) and the "new" Rule of Law is on the far right (economic, collective and international).

Such a simple explanation is insufficient, however, for the old view had something to say about both sides of the structure.

This first intuitive connection, then, does not tell the whole story because the pairs can also be related in other, opposite ways. For example, economic rights can reside in individuals, and, as in one strand of minority protection doctrine, political rights could be collective. Moreover, if the nation is the relative group, a national scheme can be seen as internationally giving deference to the achievement of collectively viewed rights. An international scheme, however, by bypassing the nation, can be seen as profoundly individual in its interpretation of rights. Leaving out the middle step, it is clear that political and economic rights can both be either national or international. The key, however, is that while each notion is compatible with either half of each other opposition, it can never be both at once. The appearance of complementarity is achieved by manipulating this flexibility. The structure of these conflicts is extremely fluid, and although the oppositions seem related, they do not seem related in any one fixed way.

It seems that the "old" view did when it adopted the rosy view that the Rule of Law could be all these things simultaneously, was not simply to deny one or the other or to emphasize their complementarity. They are not really so much complementary, after all, as reversable. What the old view did was to exploit precisely this fluidity between the various oppositions to move among them until the conflict seemed to disappear. When one opposition seemed in conflict, it was possible to shift to another which then seemed complementary. For example: economic and political rights (in conflict) could be internationally a matter of national interpretation (complementary). Or: the Rule of Law could be both national and international (in conflict) because it provided for collective solidarity in choosing rights for individual consumption (complementary). The old view, then, was able to remain wholistic by exploiting the connections between these conflicts to make them seem complementary.

In the old view the Rule of Law could ensure human dignity because it could provide economic, collective, international security without denying political and individual or national freedom. But, paradoxically, it achieved this by exploiting the fact that political rights were also collective, international schemes and economic rights were also individualistic, and so forth. That being so, the achievement of each single goal denied as well as affirmed itself. That ist, it was not that a wholistic Rule of Law needed to conquer conflict to preserve a wholistic dignity, but that these conflicts repeatedly mirrored the dual nature of human dignity; as, for example, something to be achieved alone and with 
others. The old view, then was doomed either to obscure a conflict which could not be resolved, or to deny half of what it tried to protect.

The ICJ's current initiative is significant because the "new" Rule of Law recognizes and moves beyond this failure. The conference found the traditional view that economic rights covered everything political rights left unsaid insufficient. Development meant more than the simultaneous achievement of economic and political rights for individuals and groups nationally and internationally. These old conflicts seemed both irrelevant and yet unavoidable in the old vision. The conference seems to have recognized that these conflicts resulted from an inadequate understanding of human dignity which missed much of the richness of what development might achieve. Dignity was all of these things, also in their contradictory manifestations. The time had come to embrace and transcend these contradictions, not to obscure them.

Participants described this reorientation in a number of ways of which perhaps the most characteristic was the use of the term "solidarity" or "third generation" rights in a "structural" approach to the achievement of human dignity. On the one hand these ideas fully embraced past notions of economic and political rights, and one might well understand the view that they added nothing new, but merely reemphasized the ICJ's commitment to the full realization of both. But one had the feeling the conference wanted to draw on deeper, older notions of fraternity and solidarity to avoid discussion of the alternative dimensions of the old Rule of Law. "Solidarity rights" means never having to say that a rule of law can simultaneously achieve the various forms of rights previously envisioned or that their achievement was the essence of human dignity. This amounts to a profound, if unrecognized, rejection of the Rule of Law as previously understood.

That is the meaning of the new Rule of Law. It refuses to pretend that political and economic rights can be rendered compatible simply by argument. In a significant way this is the end of an understanding of the Rule of Law as a system of "rights" altogether. In the new view, law does not structure claims between people or connections between goals and outcomes, but focuses on conditions themselves. It is a more active approach. It leaves the idea of neutral distance behind as unrealistic, for the attempts to neutrally render conflicts compatible failed to apprehend the nature of the conflict in our social vision. The new view would deal directly with development and dignity without the intermediate step of economic or political rights. Moreover, the new view would deny law's separation from other modes of thinking and other social structures. Law's special status, after all, was based on its purported ability to resolve through neutral argument, in contrast to moral or political discussion, basic conflicts inherent in the search for human dignity. As this has turned out not to be possible, the justification for law's special status disappears. Legal thinking, then, is just thinking. If our hearts and minds are touched by the indignity of underdevelopment we must respond, as lawyers as well as people. 


\section{Development and the new rule of law: New tasks for lawyers and institutions}

The notion of the Rule of Law initiated by the ICJ conference could alter our understanding of the development process and the role of both the Rule of Law and of Lawyers. The ICJ has done more than switch tactics or reorder priorities.

At the very least, the Conference de-emphasized the importance of "rights" in the international legal fabric. Some might argue this occurred by diluting existing rights with a very fuzzy notion of a right to development. Others might argue that the switch was more profound: that the creation of "rights" seemed inappropriate in the development area. The point of the new Rule of Law is that lawyers can no longer respond to hunger by debating a "right" to food.

Although much of the conference's attention was devoted to consideration of whether there was a "right to development", this discussion had an air of irreality about it. The conference as a whole emphasized the inappropriateness of responding to the threat underdevelopment posed to human dignity with traditional discussions about legal rights and duties. By moving to an approach focusing on solidarity, the conference implicitly recognized that the law, so as also lawyers, should be judged by action in producing development, not resolution of abstract conflicts. But if the discussion of a "right to development" seemed ironically without the spirit of the new Rule of Law, it succeeded in drawing attention to the importance of solidarity concerns. If calling it an international "right" helps get lawyers over the hurdle of failing to develop the sort of international solidarity taken for granted within Western societies, so be it.

Just as the role of a distant law in bringing about development was deemphasized, the role of an active community law in building self reliance and solidarity was strengthened. The task of law seems no longer reconstruction of a Western institutional or conceptual structure to guarantee either process rights or substantive conditions, internationally or within third world societies. Rather law seems a tool of communication for building the kind of solidarity larger models of development represented by economic and political rights in fact denied.

Deep within the view that political, economic and social rights were not all there was to development, then, lurks the notion that their pursuit in fact misunderstood development. Basic to the notion of development dicussed at the conference was the view that both Western and Soviet models were inappropriate. The goal of an action oriented new Rule of Law is to provide the communication tools necessary to build a model of development appropriate for local communities based on solidarity rather than upon either individualism or communalism.

It remains to be seen how the Commission will implement its new conception. Beyond pointing the direction such a new orientation in thinking about the Rule of Law might take development work, the conference did little more than recognize the contribution lawyers may have to make. Some hints about the nature of that contribution did emerge. Fundamental is abandonment of Western municipal models. One could expect the ICJ to urge the legal profession to stop thinking about development and human rights on the 
international level as another outlet for domestically tested legal roles. That is, international institutions should get out of the business of developing opinions about what counts as a "right", of judging violators and focusing on punishment of the victim. Rather, the law should be concerned with communication between victim and violator, support for the victim, and reestablishment of the conditions under which human dignity could by respected. In providing legal service in developing countries, we should de-emphasize application of the old Rule of Law to more and more levels of society with its emphasis on adversarial proceedings, rights, duties, and judgement. Spreading such a structure fools clients that justice or dignity in its contradictory senses can and in fact has been achieved. Moreover it encourages growth of inappropriate institutional structures and conflict rather than cooperation. The provision of legal service should be concerned to develop localized structures for communicating about and overcoming conflicts by developing solidarity, rather than encouraging the principled conflict resolution familiar from Western legal structures. If lawyers want to focus on developing codes of conduct, they should be codes for measuring development which could provide the basis for agitation, investigation and promotion.

The 1981 Conference of the International Commission of Jurists began a transformation from an ethnocentric western model on the Rule of Law to an approach compatible with building the solidarity necessary for human development. In doing so it has both threatened notions of the meaning and value of the Rule of Law and begun to define new tasks and goals $k^{-}$the legal profession internationally. 